\title{
A Review on Leaf Area Index of Horticulture Crops and Its Importance
}

\author{
${\text { Prabhugouda } \text { Patil }^{1 *} \text {, Pradeep Biradar }}^{2}$, Anuradha U. Bhagawathi ${ }^{3}$ \\ and Iranna S. Hejjegar ${ }^{4}$ \\ ${ }^{1}$ Department of Fruit science, College of Horticulture, Rajendranagar, Hyderabad \\ (Telangana), India \\ ${ }^{2}$ AEEC, Koppal (Karnataka), India \\ ${ }^{3}$ Department of Horticulture, UAS, Raichur (Karnataka), India \\ ${ }^{4}$ Department of Vegetable science, College of Horticulture, Mojarla, Hyderabad \\ (Telangana), India \\ *Corresponding author
}

\section{A B S T R A C T}

\section{Keywords \\ Leaf-area index, \\ Canopy size, Canopy \\ architecture, \\ Transpiration and \\ evaporation}

Article Info

Accepted:

07 March 2018

Available Online:

10 April 2018
Leaves represent the largest quantity of the total canopy surface and also the main surface for physiologically active interchange with the atmosphere. Processes like photosynthetic light absorption, carbon uptake and assimilation, transpiration of water and emission of volatile organic compounds are nearly exclusively performed via leaf surfaces, while processes like element deposition, interception of rain, evaporation and susceptibility to wind damage are in part also dependent on the surface area of woody canopy elements. Fruit production and quality depend on adequate source-sink relationships. Carbohydrates $(\mathrm{CH})$ translocated from leaves or reserve organs are the most important for the growth and development of sink organs (mainly fruits). Leaf Area Index (LAI) measures the amount of leaf quantifiable in an ecosystem, which imposes important controls on photosynthesis, respiration, rain interception and other processes that link vegetation to environment.

\section{Introduction}

Leaves are the most important structure for photosynthesis and a process which was described by Kozlowski and Pallardy (1997) in which light energy is apprehended by green plants (mainly by the chlorophyll in leaves) and used to produced reduced carbon compounds from carbon dioxide and water and also, leaf is an important plant organ and is associated with photosynthesis and evapotranspiration; therefore, leaf area capacities are required in most physiological and agronomic studies concerning plant growth (Guo and Sun, 2001). Dejong and Ryugo (1998) and Friedrich and Fischer (2000) showed the influence of various factors on photosynthesis in fruit species. Photosynthesis yields carbohydrates for growth and dynamism (Lakso and Flore, 2003) and photo synthates constitute up to $90 \%$ of a plant's dry matter (DM) (Daie, 1985) and both growth and cropping depend on a ready source of carbohydrates and 
nutrients (Oliveira and Priestley, 1988), so that Leaf area index is one of the most important parameters for canopy architecture. According to a common definition it computes the onesided area of leaf surface per unit of horizontal ground area (Watson, 1947). A more accurate description is given by Chen and Black (1992), characterizing the LAI as half of the area of completely evolved leafs per unit of horizontal ground area, thus making it independent of geometrical leaf attributes. Minimum quantities of leaf area and shoot structure are required for setting large fruit crops (Lakso Flore, 2003). Equated to annual crops (e.g., cereals), little information about the leaf area index (relationship between leaf area and occupied soil area) is known about fruit species. The leaf area index in coincidence with sunlight interception is useful as a basis for analyzing canopy productivity (Fischer, 2011). Photosynthesis is without doubt the process that has been studied and modelled the most, not least because of the direct effect of $\mathrm{CO}_{2}$ on photosynthetic rate.

However, at the more integrated plant and ecosystem level there is little evidence for an extrapolative relationship between leaf photosynthesis and growth. Instead, biomass production is closely related to light interception, which is mainly determined by leaf area index, as has been confirmed for agricultural crops (Monteith, 1977) and other vegetation types (Hirose et al., 1997). Leaf area index varies depending on a number of factors including recurrent climate, water and nitrogen availability and to some extent $\mathrm{CO}_{2}$ elevation (e.g. Drake et al., 1997; Ewert and Pleijel, 1999; Hartz- Rubin and DeLucia, 2001; Kimball et al., 2002; Cowling and Field, 2003). Recent investigations suggest that canopy photosynthesis increases with leaf area index (Rochette et al., 1995, 1996; Campbell et al., 2001; Rodriguez et al., 2001) and that effects of elevated $\left(\mathrm{CO}_{2}\right)$ on canopy photosynthesis decrease as leaf area index increases (Brooks et al., 2000). Understanding of the relative importance of such relationships for vegetation growth and productivity is limited but essential for modeling systems responses to $\mathrm{CO}_{2}$. The leaffruit ratio is species, cultivar and geographic location dependent. The optimal leaf area in various species is $200 \mathrm{~cm}^{2}$ per $100 \mathrm{~g}$ of fruit (Gerhard Fischer et al., 2012). The aim of this review is to provide some clarification about the relative importance of LAI for plant responses in horticulture crops and to discuss related about leaf area index estimation methods in different crops.

\section{Areas of application and its importance in horticulture crops}

The leaf area index is of topmost significance for eco-physiology in many ways: in demonstrating, it serves as a scaling factor, controlling processes like photosynthesis and evapotranspiration (Weiss et al., 2004; Bréda, 2003).Substitute as transition zone between plant and atmosphere, most processes of gas and water exchange as well as the interception of rain water; take place on the surface of leaves (Bréda, 2003). By extinction of incident radiation, variations in the leaf area index influence the micro climate within and above the canopy (Welles, 1990).There have been relatively few reports on the photosynthesis of fruit species which can differ greatly with diverse measuring methods and equipment used depending on the prevailing environmental conditions. Flore and Lakso (1989) summarized maximum photosynthetic rates (in $\hat{A} \mu \mathrm{mol} \mathrm{CO}_{2} \mathrm{~m}^{-2} \mathrm{~s}^{-1}$ ) for various fruit species such as the avocado (Persea americana, 4.8 \pm 2.4 ), orange (Citrus sinensis, 9.9 \pm 1.6 ), peach (Prunus persica, 13.3 \pm 3.8 ),

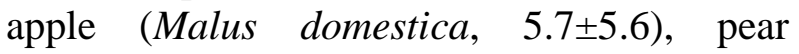
(Pyruscommunis, 20.2), grapevine (Vitisvinifera, 12.4 \pm 1.4 ), blueberry

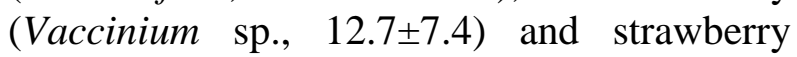


(Fragaria $\times \quad$ ananassa, 13.9 2.9 ). Photosynthetic rates of 8.33 Â $\mu$ mol $\mathrm{CO}_{2}$ $\mathrm{m}^{-2} \mathrm{~s}^{-1}$ have been measured for solanaceous species such as the cape gooseberry (Physalis peruviana) on the Bogota Plateau (Melgarejo and Fischer, 2013). Medina (2003) measured photosynthetic rates of 4-8 Âmol $\mathrm{CO}_{2} \mathrm{~m}^{-2} \mathrm{~s}^{-1}$ for the lulo (Solanum quitoense) in mountain rain forest conditions of Antoquia (Colombia). Leaves accumulate $\mathrm{CH}$ at a high rate, e.g., 8 $\mathrm{mg} \mathrm{g}^{-1}$ day $^{-1}$ of dry weight (DW) in citrus (Citrus sp.), although leaves usually contain only a small proportion of the total amount of the fruit tree (Kozlowski and Pallardy, 1997). The leaf area index in the apple lies between 1.5 and 5 depending on the variety, rootstock, pruning, trellising, fertilization and other cultural practices Jackson (1980). Rajan et al., (2001) reported that in the tropics, some mango (Mangifera indica) cultivars well improved to subtropical conditions develop large crowns with dense foliage, causing poor light penetration, flowering and fruit quality. These authors studied canopy traits of 26 Indian mango varieties on 10-year-old trees, planted at $10 \times 10 \mathrm{~m}$, measuring an average leaf area index of 2.94 (1.18-4.48). The fraction of the light passing through the canopy (DNI, diffuse non-interceptance) ranged from 0.02 to 0.36 (maximum is 1 ). The index in the peach is generally higher, between 7 and 10 (Faust, 1989). The leaf area index is higher than 1.5 in the apple. Moreover, height and type of training define light penetration to the foliage (Faust, 1989). The leaf area index in the orange can be as high as 9 or 11 (Dussi, 2007). The varieties with a low leaf area index and high DNI ('Fernandin', 'Papatio', 'MalihabadSafeda' and 'Rataul') were better exposed to solar radiation and produced more reproductive stems and good color fruits than varieties with denser foliage (Rajan et al., 2001). The interaction between vegetation surface and the atmosphere, e.g. radiation uptake, precipitation interception, energy conversion, momentum and gas exchange, is substantially determined by the vegetation surface (Monteith and Unsworth, 1990). During vegetation period of deciduous trees, total vegetation surface itself is mainly composed of leaf area, and by lesser part of twigs, branches and stem surface. Whereas during times of absent foliage (i.e. winter in temperate climates, dry season in tropical areas) woody parts determine vegetation surface area, and the leaf area index (LAI) of a forest species is a major determinant of its water balance. Allometric relationships, which are the change in proportion of various parts of an organism as a consequence of growth, exist to relate the leaf area of a tree to stem or canopy characteristics (Whitford et al., 1995; West et.al., 1988). Cohen and Naor (2002) measured the average leaf area index in Golden Delicious variety as 2.4 for M9 and as 2.7 for M109 and seedling. Lakatos (2004) established the total leaf area as 4.4-19.5 m2. Liu et al., (2001) determined that the leaf area changed according to the rootstocks but there was no change in leaf area index.

\section{Relationship between Leaf Area Index (LAI) and yield per tree}

The leaf area index (LAI) is an important parameter in crop growth. It reflects the leafiness of the crop. The leafiness in one way reflects the photosynthetic capability of the crop. The development of the fruit size depends on a number of factors such as the leaf-fruit ratio, leaf area index, genetic and climatic factors, position in the plant and the branch, tree age, number of seeds and water and nutrient supply (Dennis, 1996). For a full crop, most fruit species will set more fruit than needed if growing conditions are optimal (Westwood, 1993). LAI values related to treatments ranged from 0.32 to 0.52 in 2007, 0.73 to 1.12 in 2008 . LAI values increased by approximately $126.3 \%$ for all treatments. In both years, generally, the highest LAI values 
were observed in drip irrigation (D) for both varieties. Linear correlation $(r=0.99, n=16)$ was obtained between fruit yields and leaf area index (LAI) values of the apple trees (UlasSenyigit et al., 2013). The relations between LAI and fruit productivity, and between crown density and fruit productivity showed that fruit productivity hardly changed when LAI and crown density were lower than 5 and $80 \%$, respectively, but decreased when they were over these values An increase in yield for early-stage trees was mainly dependent on a rapid increase in LAI or crown density and a subsequent decrease in yield was mainly dependent on a large decrease in fruit productivity in Satsuma mandarin (Sunaotachibana, 1990). Mean total and spur canopy LAI and light interception were significantly and positively correlated with fruit yield (Jens $\mathrm{N}$ Wunsche and Alan $\mathrm{N}$ Lakso, 2000). Cittadani et al., (2008) reported that the relationship between fruit quality and fruit number to leaf area ratio on trees of nearoptimal LAI allows optimization of high yields with favorable quality in 'Bing' Sweet Cherry. Roper and Loescher (1987), studying the relation between leaf area and fruit quality of 'Bing' sweet cherry using isolated spurs, found that in the growing conditions of Washington State, leaf area per fruit accounted for 66, 36 and $53 \%$ of the variability in fruit weight, fruit colour and soluble solids, respectively. An increase of $1 \mathrm{~g}$ in fruit weight was predicted to require an additional 30 to $32 \mathrm{~cm} 2$ of LA. Leaf area per spur accounted for 54, 27 and $28 \%$ of the variability in the same fruit quality parameters. Hardon et al., (1969) found increases in bunch yield with increasing LAI in excess of 5.0 in oil palm.

\section{How to measure the leaf area index}

Leaf Area Index is an important measure of canopy structure because tree morphology, leaf orientation and distribution influence LAI estimates. Trees of different species can have therefore very different LAI values. LAI was first well-defined in the year of 1947 as the total one-sided area of photosynthetic tissue per unit ground surface area. Jonckheere et al., (2004) concluded that LAI is defined as one half of the total leaf area per unit ground surface area. They also noted that different definitions can result in significant differences between calculated LAI values. LAI is a dimensionless quantity $\left(\right.$ or $\mathrm{m}^{2} / \mathrm{m}^{2}$ ).

A methodology was developed to estimate the leaf area index (LAI) of cucumber and tomato plants through the evaluation of the leaf area distribution pattern (LADP) of the plants and the relative height of the leaves in the plants. Plant and leaf height, as well as the length and width of all leaves were measured and the area of some leaves was determined by a digital area meter. The obtained regression equations were used to estimate the leaf area for all relative heights along the plant and after that that they concluded that the LAI estimations presented high precision and accuracy when the proposed methodology was used resulting in time and effort savings and being useful for both crops (BlancoFlávioFavaro; Marcos ViníciusFolegatti, 2003). Watson (1947) proposed the term leaf area index which is the ratio of the leaf area of a plant to the ground area occupied by the plant.

Total leaf area of the plant

Leaf area index $=$

Ground area occupied by the plant

There are two main categories of procedures to estimate LAI: direct and indirect methods (Gower et al., 1999). The former group consists of methods measuring leaf area in a direct way, while the latter group consists of methods where LAI is derived from more easily (in terms of time, workload and technology) measurable parameters (Fassnacht et al., 1994; Gower et al., 1999). 
Fig.1 Leaf area index of Guava (Psidium guajava) by digital plant canopy imager (CID Bio Science, Inc)

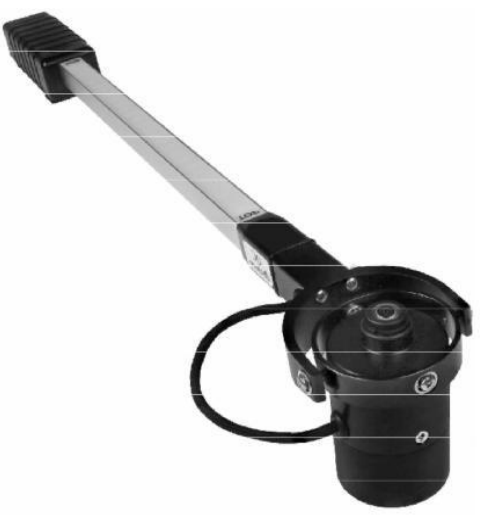

Direct methods

Direct methods are accurate but labour intensive and therefore used in a limited way.

They consist of two steps, leaf collection and leaf area measurement.

\section{Harvesting methods}

\section{Destructive sampling}

Collection and removal of green leaves from a sampling plot. b) "Model tree" method:

Destructive sampling of a small amount of representative trees out of the stand, from which the leaf area and vertical distribution of leaf area is measured leaf by leaf.

\section{Non-harvest methods}

Leaf litter collection during the leaf-fall period employs "traps" (open boxes with predetermined size and lateral sides that prevent wind blowing leaves into or out of the traps).

There seems to be no consensus on the sampling design of the traps (Jonckheere et al., 2004).

\section{Leaf area determination}

Leaf area can be calculated by means of either planimetric or gravimetric techniques.

\section{Planimetric approach}

Based on the correlation between the individual leaf area and the number of area units covered by that leaf in a horizontal plane (Jonckheere et al., 2004). Leaf perimeter can be measured with a planimeter, and its area then computed. Special instruments have been designed for this purpose.

\section{Gravimetric method}

Based on the correlation between dry weight of leaves and leaf area using predetermined leaf mass per area (LMA, determined from a sub-sample). Once the LMA is known, the entire field sample is oven-dried and leaf area is calculated from its dry-weight and the subsample LMA (Jonckheere et al., 2004). LMA variability represents a source of uncertainty.

\section{Indirect methods}

In indirect methods, leaf area is inferred from observations of another variable. They are generally faster, amendable to automation, 
and thereby allow for a larger spatial sample to be obtained, thus they are becoming increasingly important (Jonckheere et al., 2004).

\section{Indirect contact LAI measurements}

Inclined point quadrat: it consists of penetrating a vegetation canopy with a long thin needle at specific angles and counting the number of contacts with "green" canopy elements. The principal disadvantage of the method is the large numbers of points needed making the technique laborious, and its unsuitability for canopies exceeding $1.5 \mathrm{~m}$ in height (Jonckheere et al., 2004). Breda (2003) reviewed an approach of light transmittance measurement through a canopy to obtain information on daily of LAI changes within a stand. The indirect non-contact measurements do not distinguish photosynthetically active leaf tissue from other plant elements such as stem, branches or flowers, and corrections are therefore required. Another important complicating factor is the clumping of individual needles on branches of needle leaf species which leads to LAI underestimation; correction methods have also been developed for this effect (Weiss et al., 2004; Jonckheere et al., 2004).

\section{Existing satellite measurement methods and standards}

Morisette et al., (2006) reviewed the techniques employed in various countries to produce and evaluate LAI products derived from satellite measurements. They also identified the required elements for an international satellite-based products validation effort: an organizational entity, the willingness of participants to improve the consistency between methods and results, a mechanism for sharing the data along with a description of the procedure used, and the synthesis of data and results into global accuracy statements. Leaf area index in fruit crops (Fig. 1) was calculated with using an instrument called digital plant canopy imager (CID Bio Science, Inc). Leaf area index is the ratio of foliage area to ground area. Canopy imager is having optical sensor consists of fisheye lens and an optical system. The fish eye lens sees a hemispherical image, which the optical system focuses onto the photodiode optical sensor, which is made up of five concentric rings.

Minimum quantities of leaf area and shoot structure are required for setting large fruit crops (mango, guava, Sapota and Strawberry) and as compared to annual crops (e.g., cereals), little information about the LAI (relationship between leaf area and occupied soil area) is known about horticulture plants; so that the significance of the leaf area index is more to know the LAI in combination with sunlight interception is useful as a basis for analyzing canopy productivity. So, leaf area index is an important measure of canopy structure because tree morphology, leaf orientation and distribution influence LAI estimates. Trees of different species can have therefore very different LAI values.

\section{References}

Blanco, F. F., Folegatti, M.V. 2003. A new method for estimating the leaf area index of cucumber and tomato plants. Horticultura Brasileira, Brasília, v. 21, n. 4, p. 666-669, outubro/dezembro.

Bréda, N.J.J. 2003. Ground-based measurements of leaf area index: a review of methods, instruments and current controversies. J. Exp. Bot. 54, 24032417.

Bréda, N.J.J., Granier, A. 1996. Intra- and interannual variations of transpiration, leaf area index and radial growth of a sessile oak stand (Quercuspetraea), Ann SciFor 53: 521-536 
Brooks TJ, Wall GW, Pinter PJ, Jr, Kimball BA, LaMorte RL, Leavitt SW et al., 2000. Acclimation response of spring wheat in a free- air $\mathrm{CO}_{2}$ enrichment (FACE) atmosphere with variable soil nitrogen regimes. 3. Canopy architecture and gas exchange. Photosynthesis Research.66: 97-108.

Campbell CS, Heilman JL, McInnes KJ, Wilson LT, Medley JC, Wu G, Cobos DR.2001. Seasonal variation in radiation use efficiency of irrigated rice. Agricultural and Forest Meteorology.110: 45-54.

Chen, J. M., Black, T. A., 1992. Defining LeafArea Index for Non-Flat Leaves. Plant Cell.Environ.15: 421-429.

Cohen S. and Naor, A. The Effect of Three Rootstock on Water Use, Canopy Conductance and Hydraulic Parameters of Apple Trees and Predicting Canopy from Hydraulic Conductivity. Plant, Cell and Environment. Vol.25, No.1, 2002, pp.1728.

CowlingSA, Field CB.2003. Environmental control of leaf area production: implications for vegetation and land- surface modeling. Global Biogeochemical Cycles 17: 1-14.

Daie, J. 1985. Carbohydrate partitioning and metabolism in crops. Hort. Rev. 7, 69108.

DeJong, T.M. and K. Ryugo. 1998. Carbohydrate assimilation, translocation, and utilization. pp. 109-114. In: Ramos, D.E. (Ed.). Walnut production manual. UC ANR Publication 3373 (http:// anrcatalog.ucdavis.edu/Nuts/3373.aspx). University of California, Oakland, CA

Dennis, F.G. 1996. Fruit development. pp. 107116. In: Maib, K.M., P.L. Andrews, G.A. Lang, and K. Mullinix (eds.). Tree fruit physiology: growth and development. Good Fruit Grower, Yakima, WA.

DrakeBG, Gonzalez- Meler MA, Long SP.1997. More efficient plants: a consequence of rising atmospheric $\mathrm{CO}_{2}$. Annual Review of Plant Physiology and Plant Molecular Biology. 48: 609-639.
Dussi, M. C. 2007. Intercepcion y distribucionluminica en agrosistemasfruticolas. Pp. 200-241. In: Sozzi, G. (Ed.). Árbolesfrutales: ecofisiología, cultivo y aprovechamiento. Editorial Facultad de Agronomía, Universidad de Buenos Aires, Buenos Aires.

EwertF, Pleijel H.1999. Phenological development, leaf emergence, tillering and leaf area index, and duration of spring wheat across Europe in response to $\mathrm{CO}_{2}$ and ozone. European Journal of Agronomy.10: 171-184.

Fassnacht, K.S., Gower, S.T., Norman, J.M., McMurtrie, R.E., 1994. A comparison of optical and direct methods for estimating foliage surface area index in forests. Agric. For. Meteorol.71: 183-207.

Faust, M. 1989. Physiology of temperate zones fruit trees. John Wiley and Sons, New York. Fischer, G. 1995. Effect of root zone temperature and tropical altitude on the growth, development and fruit quality of cape gooseberry (Physalis peruviana L.). Ph.D. thesis. Humboldt-Universitätzu Berlin, Berlin.

Fischer, G. 2005. Aspectos de la fisiologíaaplicada de los frutalespromisorios en cultivo y poscosecha. Rev. Comalfi. 32(1), 22-34.

Fischer, G. 2011. La relaciónhojalfruto en especiesfruticolas. Pp. 40-53. Proc. 4th Colombian Congress of Horticulture, Palmira, Colombia.

Flore, J. A. and Lakso, A. N. 1989.Environmental and physiological regulation of photosynthesis in fruit crops.Horticulture Reviews. 11: 111-157.

Friedrich, G. and M. Fischer. 2000. Physiologischegrundlagen des obstbaues. ulmerverlag, Stuttgart, Alemania.

Gerhard Fischer, Pedro José Almanza-Merchán, Fernando Ramírez. 2012. Source-sink relationships in fruit species: a review. Revistacolombiana de cienciashortícolas vol. 6 - no. 2 - pp. 238-253.

Gower, S. T., Kucharik, C. J., Norman, J. M., 1999. Direct and indirect estimation of leaf area index, Faparand Net Primary 
Production of terrestrial ecosystems. Remote Sens. Environ. 70, 29-51.

Guo, D.P.; Sun, Y.Z. Estimation of leaf area of stem lettuce (Lactuca sativa varangustana) from linear measurements. Indian Journal of Agricultural Sciences, v. 71, n. 7, p. 483-486, 2001

Hardon, J J; Williams, $\mathrm{C} \mathrm{N}$ and Watson, I. (1969). Leaf area and yield in the oil palm in Malaya. Expl. Agric.5: 25-32.

Hartz- Rubin JS, DeLucia EH.2001. Canopy development of a model herbaceous community exposed to elevated atmospheric $\mathrm{CO}_{2}$ and soil nutrients. Physiologia Plantarum 113: 258-266.

Hirose T, Ackerly DD, Traw MB, Ramseier D, Bazzaz FA.1997. $\mathrm{CO}_{2}$ elevation, canopy photosynthesis, and optimal leaf area index. Ecology 78: 2339-2350.

Jens N wunsche and Alan N Lakso, 2000. The relationship between leaf area and light interception by spur and extension shoot leaves and apple orchard productivity. HortScience. (35)7:1202-1206.

Jonckheere, I., Fleck, S., Nackaerts, K., Muys, B., Coppin, P., Weiss, M., Baret, F., 2004: Review of methods for in situ leaf area index determination: Part I. Theories, sensors and hemispherical photography. Agric. For. Meteorol. 121: 19-35.

Kimball BA, Kobayashi K, Bindi M.2002. Responses of agricultural crops to free- air $\mathrm{CO}_{2}$ enrichment. Advances in Agronomy.77: 293-368.

Kozlowski, T. T. and S.G. Pallardy. 1997. Physiology of woody trees. 2nd ed. Academic Press, San Diego, CA.

Lakatos, T. Effects of Crop Load on Tree Water Use in Apple (Malus x DomesticaBorkh.). ActaHort. (ISHS) 646, 2004, p.55-61.

Lakso, A. N. and Flore, J. A. 2003.Carbohydrate partitioning and plant growth.21-30.

Liu, L., McDonald, A.J.S., Stadenberg, I. and Davies, W.J. Stomaland Leaf Growth Responses to Part Drying of Root Tips in Willow. Tree Physiology 21, 2001, p. 765-770.
Mature Norway spruce Stands of Eastern Germany. Can. For. Res., 30: 440-447.

Medina, C.I. 2003. Estudio de algunosaspectosfisiológicosdellulo (Solanum quitoense Lam.) en el bosquehúmedomontañobajodelorienteanti oqueño. M.Sc. thesis. UniversidadNacional de Colombia, Medellin, Colombia.

Melgarejo, L.M. and G. Fischer. 2013. Ecophysiological response of cape gooseberry (Physalis peruviana L.) to the environmental conditions of the Bogota Plateau (in preparation).

Monteith JL, Unsworth MH, 1990. Principles of environmental physics. Edward Arnold, London, $291 \mathrm{pp}$.

Monteith JL. 1977. Climate and the efficiency of crop production in Britain. Philosophical Transactions of the Royal Society of London, Series B 281: 277294.

Morisette, J.T., Baret, F., Privette, J.L., Myneni, R.B., Nickeson, J.E., Garrigues, S., Shabanov, N.V., Weiss, M., Fernandes, R.A., Leblanc, S.G., Kalacska, M., Sánchez-Azofeifa, G.A., Chubey, M., Rivard, B., Stenberg, P., Rautiainen, M., Voipio, P., Manninen, T., Pilant, A.N., Lewis, T.E., Iiames, J.S., Colombo, R., Meroni, M., Busetto, L., Cohen, W.B., Turner, D.P., Warner, E.D., Petersen, G.W., Seufert, G., and Cook, R. 2006. Validation of Global ModerateResolution LAI Products: A Framework Proposed Within the CEOS Land Product Validation Subgroup. IEEE Transactions on Geoscience and Remote Sensing 44: 1804-1817.

Oliveira, C.M. y C.A. Priestley. 1988. Carbohydrate reserves in deciduous fruit trees. Hort. Rev. 10, 403- 430.

Rajan, S., R. Kumar, and S.S. Negi. 2001. Variation in canopy characteristics of mango (Mangifera indica L.) cultivars from diverse eco-geographical regions. J. Appl. Hort. 3(2), 95-97.

RochetteP, Desjardins RL, Pattey E, Lessard R.1995. Crop net carbon dioxide 
exchange rate and radiation use efficiency in soybean. Agronomy Journal 87: 22-28. RochetteP, Desjardins RL, Pattey E, Lessard R.1996. Instantaneous measurement of radiation and water use efficiencies of a maize crop. Agronomy Journal 88: 627635.

RodriguezD, Ewert F, Goudriaan J, Manderscheid R, Burkart S, Weigel HJ.2001. Modelling the response of wheat canopy assimilation to atmospheric $\mathrm{CO}_{2}$ concentrations. New Phytologist 150: 337-346.

Roper, T.R. and Loescher, W.H. 1987.Relationships between leaf area per fruit and quality in 'Bing' sweet cherry. HortScience 22:1273-1276.

ShailendraRajan, Ram Kumar and Negi, S. S. 2001. Variation in canopy characteristics of mango (Mangifera indica L.) Cultivars from diverse eco geographical regions. $J$. Appl.Hort. 3 (2):95-97.

Sunao tachibana.1990. Relationships between Fruit Productivity, Leaf Area Index and Crown Density, and Yield in Different Planting Densities in Wase Satsuma Mandarin (Citrus unshiu) Trees.Japan.Soc.Hort.Sci. 58(4):871$875.1 \mathrm{ggO}$.

UlasSenyigit, NecdetDagdelen, M. AtillaAşkin, Abdullah Kadayifci1, Yusuf Ucar1. 2013. Variation of leaf area index and leaf water potential of young dwarf apple trees under different irrigation methods. Polskaakademianauk, Oddział w
Krakowie, S. 85-98 Komisja Technicznej InfrastrukturyWsi.

Watson, D. J., 1947. Comparative physiological studies in the growth of field crops. I: Variation in net assimilation rate and leaf area between species and varieties, and within and between years. Ann. Bot., 11: 41-76.

Weiss, M. Baret, F. Smith, G.J. Jonckheere, I. Coppin, P. (2004). Review of methods for in situ leaf area index (LAI) determination. Part II. Estimation of LAI, errors and sampling. Agriculture and Forest Meteorology 121: 37-53.

Welles, J. M., 1990. Some indirect methods of estimating canopy structure. Remote Sensing Reviews, 5:31-43.

West, P.W. Beadle, C.L. Turnbull, C.R.A. (1988). Mechanistically based, allometric models to predict tree diameter and height in even-aged monoculture of Eucalyptus regnans F. Muell. Canadian Journal of Forest Research. 19: 270-273.

Westwood, M.N. 1993. Temperate-zone pomology. $3^{\text {th }}$ ed. Timber Press, Portland, OR. Whitford, K. R. Colquhoun, I. J.; Lang, A. R. G.; Harper, B. M. (1995)."Measuring leaf area index in a sparse eucalypt forest: a comparison of estimates from direct measurement, hemispherical photography, sunlight transmittance and allometric regression." Agriculture and Forest Meteorology.74: 237-249

\section{How to cite this article:}

Prabhugouda Patil, Pradeep Biradar, Anuradha U. Bhagawathi and Iranna S. Hejjegar. 2018. A Review on Leaf Area Index of Horticulture Crops and Its Importance. Int.J.Curr.Microbiol.App.Sci. 7(04): 505-513. doi: https://doi.org/10.20546/ijcmas.2018.704.059 